\title{
Uniqbu Journal of Social Sciences (UJSS)
}

\begin{tabular}{lll}
\hline Volume 1 & Nomor 2, Agustus 2020 & Halaman 86-94
\end{tabular}

\section{JUDICAL REVIEW OF THE CRIME OF NARCOTICS ABUSE CATEGORY I}

\author{
(Tinjauan Yuridis Terhadap Tindak Pidana Penyalagunaan Narkotika Golongan I)
}

\author{
Sofian Malik ${ }^{\text {a, }}$ Ridwan Syarif Goa ${ }^{\text {b, }}$, Darwin Rukuac, Salmah Yusuf ${ }^{\mathrm{d}}$, \& Aprie, \\ abcd Universitas Iqra Buru \\ Jalan Prof. Dr. Abd. Bassalamah, Namlea. Maluku Indonesia \\ ${ }^{b}$ Universitas Slamet Riyadi Surakarta
}

Jl. Sumpah Pemuda No.18, Kadipiro, Kec. Banjarsari, Kota Surakarta, Jawa Tengah

Pos-el: sofianmalikunibu@ gmail.com

(Diterima: 09 Agustus; Direvisi 11 Agustus; Disetujui: Agustus 2020)

\begin{abstract}
This study describes the basis for the application of material criminal law to criminal acts of drug abuse. This research was conducted in the city of Namlea, namely in the Namlea District Court using primary and secondary data methods. Data (interview) directly with the parties concerned. Meanwhile, secondary data collection techniques are carried out by reading documents or regulations and literature books related to the material to be presented in the thesis. After all the data is collected, the data is processed and analyzed qualitatively and then presented descriptively, that is, searching for and collecting data related to the object and the problem under study. Based on the results of research and discussion, it shows that: 1) in Decision No. 5 / Pid.Sus / 2020 / PN Nla, the Public Prosecutor uses the second indictment, namely Article 127 paragraph (1) letter a of the Republic of Indonesia Law No. 35 of 2009 concerning Narcotics the elements in the indictment have been deemed proven by the Public Prosecutor. that is, the acts and elements of the article match each other, and according to the author, the application of material criminal law in this case is not in accordance with the applicable criminal law in Indonesia. 2) in Decree No. 5 / Pid.Sus / 2020 / PN Nla, the author does not agree with the Panel of Judges in implementing Article 127 because the elements are not proven and do not match each other, the Panel of Judges is wrong in making decisions without looking at Articles 54, 55 and 103 of the Republic of Indonesia Constitution No.35 Years 2009 About Narcotics.
\end{abstract}

Keywords: judicial review, criminal, narcotics abuse

\begin{abstract}
Abstrak
Penelitian ini mendeskripsikan dasar penerapan hukum pidana materiil terhadap tindak pidana penyalahgunaan narkoba. Penelitian ini dilaksanakan di kota Namlea, yakni di Pengadilan Negeri Namlea dengan mengunakan metode data primer dan sekunder. Data (wawancara) langsung dengan pihak-pihak yang bersangkutan. Sedangkan teknik pengumpulan data sekunder dilakukan dengan cara membaca dokumen atau peraturan serta buku-buku literatur yang berhubungan dengan materi yang akan dikemukakan dalam skripsi. Berdasarkan hasil penelitian dan pembahasan menunjukkan bahwa: 1) dalam Putusan No. 5/Pid.Sus/2020/PN Nla, Jaksa Penuntut Umum menggunakan dakwaan kedua yaitu Pasal 127 ayat (1) huruf a Undang-Undang RI No. 35 Tahun 2009 Tentang Narkotika unsur-unsur dalam dakwaan tersebut telah dianggap terbukti oleh Jaksa Penuntut Umum. yakni, antara perbuatan dan unsur-unsur pasal saling mencocoki, dan menurut penulis penerapan hukum pidana materiil dalam kasus ini tidak sesuai dengan hukum pidana yang berlaku di Indonesia. 2) dalamPutusan No. 5/Pid.Sus/2020/PN Nla, penulis tidak sependapat dengan Majelis Hakim dalam menerapkan Pasal 127 karena unsurunsurnya tidak erbukti dan tidak saling mencocoki, Majelis Hakim keliru dalam mengambil keputusan tanpa melihat Pasal 54, 55 dan 103 UUD RI No.35 Tahun 2009 Tentang Narkotika.
\end{abstract}

Kata Kunci: Judikal review, criminal, penyalahgunaan narkotika 


\section{INTRODUCTION}

National Development cannot be separated from human life as the main motor of its driving force. Human resources are the main thing in development because development will not run without qualified human beings. Therefore, human resource development is a major priority that must be worked on, because the increasing quality of Indonesian human resources makes it a very important capital to compete in the current era of globalization.

In social interactions, every day there is a relationship between members of the community with one another. Changes in these relationships cause various events or incidents that can drive legal events. One example of this incident is the abuse of narcotics which is becoming increasingly worrying Hamzah: 2008.

Transnational narcotics crimes are committed using a modern modus operandi and sophisticated technology, including securing the proceeds of narcotics crimes. The development of the quality of narcotics crimes has become a very serious threat to human life.

Some new material in Law Number 35 of 2009 concerning Narcotics, shows that there are efforts to provide a psychological effect on society so that they do not fall into narcotics crime, it has been determined that the criminal threat is heavier, minimum and maximum considering the level of danger caused by the The abuse and illicit trafficking of narcotics seriously threatens the security of national security.

The results of a survey by the National Narcotics Agency (BNN) on the development of the world drug situation in 2014 , it is known that the estimated number of drug users in 2012 is between 162 million and 324 million people or around $3.5 \%-7 \%$. In Indonesia, it is estimated that the number of drug users in the past year is around 3.1 million to 3.6 million people or the equivalent of $1.9 \%$ of the population aged
10-59 years in 2008. The projection results of the prevalence rate of drug abusers will increase by around $2.6 \%$ in 2013. In 2014 the number of drug abusers in This country has touched the number of $4,022,702$ people, meaning $2.18 \%$ of Indonesia's population of $184,175,500$ people.

The above facts are supported by an increasing trend in the number of confiscations and disclosure of drug cases. Case disclosure data in 2006 were about 17,326 cases, then increased to 26,461 cases in 2010. Similarly, drug seizure data for the main types, namely marijuana, methamphetamine, ecstasy, and heroin.Marton, et.al: 2008.

The problem of drugs (narcotics, psychotropic substances, and addictive substances) is already a national problem, because the drug problem is everywhere. It seems that there are no more urban villages or villages in this Republic that are sterile from drugs. Whether we realize it or not, drugs already exist around us.

The problem of narcotic abuse becomes very important considering that narcotic drugs have an impact on physically and mentally, and when used in the right dose and under the supervision of a doctor or psychiatrist it can be used for medicinal purposes or research purposes, but if it is misused or used inconsistently. standard treatment can harm its users. The direct effect of narcotics, apart from being moral and physical damage, is also a deadly disease, namely HIV or AIDS as a side effect of narcotics use.

As a result of the aforementioned problems, a developmental pattern of community diseases such as crime, gambling, theft or mugging, rape, prostitution and others has emerged. Narcotics addicts and victims of narcotics abuse are required to undergo medical rehabilitation or social rehabilitation in a drug addiction rehabilitation center. Medical rehabilitation and social rehabilitation are 
intended to restore and / or develop physical, mental and social abilities of addicts, with the ultimate goal of curing addicts from narcotic addiction (Rahim: 2015)

Law enforcement against narcotics crime has been carried out by law enforcement officials and has received many judges' decisions in court hearings. It is hoped that law enforcement can act as an antidote factor against the widespread circulation of narcotics trafficking. However, in reality, the more intensive law enforcement is carried out, the increasing also the circulation of the narcotics trade.

Based on the foregoing, the author raises the title of "Judicial Review of the Crime of Narcotics Abuse Category I for Yourself (Case Study of Decision No. 5 / Pid.Sus / 2020 / PN Nla).

Based on the description that the author has put forward in the background, the following problems can be formulated: a. How is the application of material criminal law against criminal acts of narcotics abuse class I for oneself? and What is the judge's consideration in making a decision on case Number 5 / Pid.Sus / 2020 / PN Nla?

\section{THEORITICAL REVIEW Criminal}

Criminal law is a legal rule regarding criminal law. The word criminal means things that are convicted, namely by a competent agency delegated to a person as something that is unpleasant to feel and also things that are not transferred to everyday life.

According to Muladi and Barda Nawawi Arief. Criminal is suffering that is deliberately imposed upon a person who commits an act which meets certain conditions. while Roeslan Saleh emphasized that the punishment was a reaction to the offense, and this was in the form of a sorrow that the State deliberately inflicted on the offender. (Muladi and Barda Nawawi, 1998: 2).
The theories about criminalism can be divided into 3 (three) groups of theories as follows:

\section{Absolute Theory (Retributions)}

According to this theory, punishment is an absolute consequence that must exist as one of the reprisals to the person who committed the crime (quia peccatum set), where the justification of the crime lies in the existence or occurrence of a crime. According to John Andanes, the main purpose (primair) of criminal according to absolute theory is to satisfy the demands of justice (to satisfy the claims justice) while the beneficial effect is secondary. (Pipin Syarifin, 2000: 13).

\section{Relative Theory (Utilarian)}

According to this theory, punishment is not just taking revenge or retribution against a person who has committed a criminal act. but has a specific purpose that is useful where the basis for justifying the existence of crime according to theory lies in its objective. The punishment imposed is not quia peccatum est "(the person who makes the crime), but" nee peccetur "(so that people do not commit a crime), therefore according to J. Andeneas, the theory can be called the theory of social defense.

Regarding the purpose of crime, to prevent crime, there is a difference between the terms general prevention and special prevention where general prevention is intended so that the effect of the crime on the general public does not commit a criminal act, while special prevention is intended to influence the criminal against the convicted person. This means that the purpose of punishment is for the convict to change into a better and useful person for society (rehabilitations theory).

In addition to general and special prevention, van Bemmelen also includes "power to secure" (debeveileigende werking) into this theory. It was explained that it is a fact, especially the criminal deprivation of liberty, it is more secure for the public 
against crimes while the criminal is in prison than if he is in prison.

Combined Theory (Verenignings Theorieen) According to this theory, the purpose of punishment is plural because it connects the principle of the goal and the principle of retaliation in one unit. In this case, punishment and punishment consist of a process of activity against the perpetrator of a criminal act, which in a certain way is expected to assimilate the prisoner back to society. Simultaneously, society demands that we treat that individual as well as satisfying a retaliatory request or need. Furthermore, it is hoped that this treatment can support these goals. (Pipin syarifin).

Based on the above opinions, it can be analyzed that in a crime contains elements, namely that the punishment is essentially an imposition of suffering or other unpleasant consequences, the punishment is given intentionally by a person or body who has the power (by the competent authorities) and the punishment is imposed on someone who has committed a criminal act, in which the crime or act is contrary or prohibited by law.

\section{Criminal Types}

According to the positive criminal law (KUHP) and outside the KUHP, these types of crimes according to the Criminal Code are opposed or prohibited by law.

$\checkmark$ The main crimes, namely:

- Death penalty

- Criminal imprisonment

- Penalty of confinement

- Criminal fines

- Crime of cover (added based on law number 20 of 1946)

Additional criminal

- Revocation of certain rights

- Confiscation of certain items

- Announcement of the judge's decision

crimes in positive criminal penalties, there are also types of actions, for example:
- Placement in a mental hospital for a person who cannot be held accountable because his / her soul is disabled in growth or is disturbed by illness. (See and so on are regulated in Article 44 paragraph (2) of the Criminal Code).

- For children who before the age of 16 commit a crime. Judges can impose actions in the form (see article 45 of the Criminal Code but it has been revoked since the existence of law number 3 of 1997 concerning juvenile justice):

- Return to their parents, guardians or carers; or

- Ordering the child to be handed over to the government. in the case of (2) the child is admitted to a state education house, the organizer of which is regulated by forced education regulations.

- Placement in the State work place for unemployed people who are lazy to work and do not have a livelihood and disturb public order by begging, homeless or social activities.

- Orderly action in the case of economic crime

In relation to these types of crimes, the government has repeatedly formulated or improved through the draft version of the draft version of the 1972 KUHP revision, the draft draft of the draft KUHP book 1 of 1982/1983 compiled by the BPHN legal review team, and the draft KUHP 200 chaired by muladi. (Muladi and Barda Nawawi Arief, 2005: 48). Based on the description above, it can be said that with regard to the types of crimes in the latest development concept, the main criminal is imprisonment, imprisonment, supervision, fines, and social work. 


\section{Criminal act}

The term criminal offense is a translation from the Dutch language, namely Strafbaarfeit or delict which comes from the Latin delictum. While the word "feit" itself in Dutch means "part of reality" or "een gedeelte van werkelijkheid" while "strafbaar" means "can be punished", so literally the word "strafbaar feit" can be translated as "part of a a punishable reality.

According to Amir Ilyas, criminal action is a term that contains a basic meaning in legal science as a term formed with the awareness of giving certain characteristics to criminal law events. Criminal action has an abstract meaning from concrete events in the field of criminal law, so that criminal action must be given a scientific meaning and is clearly defined in order to be able to separate it from the terms used daily in public life."

Furthermore, the term criminal action indicates the meaning of the actions of a person's behavior and physical movements. This makes a person not to act, but by not doing so he has committed a criminal act.

Regarding the obligation to do but he does not act, which is contained in Article 164 of the Criminal Code, the provisions of this article require a person to report to the authorities if a crime will occur, it turns out that he does not report it will be subject to sanctions (Priayanto: 2006).

So it can be concluded that a criminal act is an act which is prohibited by law and punishable by punishment, where the word action describes an active act which means "doing something which is actually prohibited by law" and a passive act which means "not doing something that is illegal. actually required by law".

\section{Drugs}

In the assumption of the wider community, drugs are an abbreviation of narcotics and dangerous drugs. These two words are an inseparable part, because all dangerous drugs tend to be understood as drugs that contain narcotics. Based on the circular letter of the National Narcotics Agency No. 03 / IV / 2002 / BNN, that the standard term used is drug, as an acronym for narcotics, psychotropic substances and other addictive substances. Drugs are substances / substances that, when put into the human body, either orally / taken orally, inhaled, or injected, can change a person's thoughts, moods or feelings, and behavior. Drugs can cause physical and psychological dependence (addiction).

Narcotics are substances or drugs derived from plants or non-plants, both synthetic and semi-synthetic, which can cause a decrease or change in consciousness. loss of pain and can lead to dependence (Law No. 35 of 2009).

\section{Narcotics abuse}

Currently the spread of narcotics and illegal drugs has reached a very alarming level. There are countless efforts to eradicate drugs by the government, but it is still difficult to avoid narcotics and illegal drugs. The driving force or the main motivator of the criminals in the field of narcotics and illegal drugs is the issue of economic gain. The narcotics and illicit drug business is growing to become one of the most favorite businesses in the world, so it is not surprising that the sale of narcotics and drugs is the same as laundering money from the narcotics and drug business. So dangerous is the consequences that can be caused in the abuse of narcotics so that Article 114 paragraph (1) of Law Number 35 of 2009 concerning Narcotics explains that:

"Everyone who is without rights or against the law in the case of narcotics, namely offering to sell, sell, buy, receive, become an intermediary in buying and selling, exchanging or handing over Narcotics Category I, shall be sentenced to life imprisonment or imprisonment of at least 5 (five). years and a maximum of 20 (twenty) years and a fine of at least Rp. 1,000,000,000.00 (one billion rupiah) and a maximum of Rp. 10,000,000,000.00 (ten billion rupiah)" 
The prohibitions as stated in Article 114 paragraph (1) above show that the law stipulates that all acts without rights or against the law misuse narcotics group I, because they are very dangerous and have an effect on increasing crime. If these acts are committed by a person or without rights, then it can be categorized as an act of narcotics abuse or a special crime that can be punished with heavy legal sanctions.

Based on the definition stated above, it can be seen that narcotics abuse is a person who uses narcotics extensively without rights or against the law on a broad basis.

\section{METHOD}

The type of research used in this research is juridical empirical research, juridical empirical research is legal research regarding the enactment or implementation of normative legal provisions in action at any particular legal event that occurs in society (Abulkadir Muhammad, 2004).

Empirical juridical research is a field research (research on primary data), which is a study examining legal regulations which are then combined with data and behavior that live in the midst of society. The main data / material in this study were obtained directly from respondents through field research.

This research was conducted at the Namlea District Court for field research, as well as the Library of the Faculty of Law, Iqra Buru University and, for library research. By conducting research at this location, the authors hope to obtain accurate data so that they can obtain objective research results related to the object of research.

This study uses types of data that come from different sources, namely:

Primary data, namely, original data obtained through field studies, from the first original source that has not been processed and described by others, to obtain direct data from respondents whose object of research is by conducting direct interviews.
Respondents in this study are;

Panel of Judges for Case 5 / Pid.Sus / 2020 / PN Nla;

Students (i) who are capable of law; Secondary data, namely, data obtained through literature study that examines laws, literature, articles, legal journals, opinions of scholars, and those related to research topics.

Secondary data used in this research are in the form of laws and regulations, including Law No. 35 of 2009 About Narcotics, as well as books about drugs.

All data that will be obtained from this research will be analyzed qualitatively and using deductive methods, qualitatively by examining the data obtained systematically and consistently to achieve clarity of the problems to be discussed.

\section{RESULTS AND DISCUSSION}

Since the researchers tried to find out the learning style in creating outstanding students with many achievements in English subject. The researchers focused on the students learning style by investigating her way of learning trough observation and interviewing the student, treacher and her friends.

Drug abuse is the use of drugs or dangerous substances for non-medicinal purposes and research and is used without following the correct rules or dosages. In conditions that are quite reasonable / according to the recommended dosage in medicine, continuous drug use will result in dependence, depression, addiction or addiction.

Drug abuse also affects the body and mental-emotional of the users. If it is consumed more often, especially in excess amounts, it will damage the health of the body, psyche and social functions in society.

According to the author, the main cause of drug dependence is due to ignorance of the dangers posed by these goods. So that it makes it difficult to return to their true identity. Factors that cause people to abuse drugs, namely: The basis of 
religion is not strong; Two-way communication between parents and children is very rare, don't want to know; Intercourse in the school environment; Environmental community influence; Culture that enters through electronic and print media.

If the drug is used continuously or in excess of a predetermined dose, it will result in dependence. This addiction will cause physical and psychological problems, due to damage to the central nervous system (CNS) and body organs such as the heart, lungs, liver and kidneys. The impact of drug abuse on a person really depends on the type of drug used, the user's personality and the situation or condition of the user. In general, the impact of drug addiction can be seen on a person's physical, psychological and social aspects.

a. Application of Material Criminal Law to the Crime of Narcotics Abuse Category $I$ for Yourself in Decision No. 5 / Pid.Sus / 2020 / PN Nla

In examining a criminal case, the judge looks for and proves the truth of material criminal law based on the facts revealed in the trial, and the judge adheres to the indictment formulated by the public prosecutor, if the indictment contains deficiencies or errors, the judge will find it difficult. considering and assessing and applying sanctions to the perpetrators of criminal acts of narcotics abuse class I for themselves, the author will first discuss the position in case decision number 5 / Pid.Sus / 2020 / PN $\mathrm{Nla}$

1) Identity of the Parties

Identity of the Defendant: DIAN RANA PUTRA Alias DIAN Alias PUTRA, 29 years old, born in Banyuwangi on March 5, 1990, male gender, Islamic religion, Indonesian nationality, merchant occupation, address Unit 11 Grandeng Village, Lolong Guba District, Kabupatn
Buru USW Unit 11 Parbulu Village, Wailata District, Buru Regency.

2) Identity of witness I: Fahmi Wael, 31 years old, born in 1988 in Kaiely Village on March 20, male gender, Islamic religion, Indonesian nationality, occupation of a member of the National Police, address of the Polres hostel.

3) Identity of witness II: Samsul B. Hatuina, 32 years old, born in 1987 in the village of Seit on May 19, male gender, Islamic religion, Indonesian nationality, occupation of a member of the National Police, address of the Polres hostel

b. Case

Initially, the defendant DIAN RANA PUTRA Alias DIAN Alias PUTRA, on Tuesday, 22 October 2019 at 11.00 WIB or at least in October 2019, was located on Jl. Towards Pontong Dusun Air Mendidih, Waenetat Village, Waeapo District, Buru Regency or at least the Namlea District Court has the authority to judge, that the defendant DIAN RANA PUTRA Alias DIAN Alias PUTRA without rights or against the law, owns, keeps, controls or provides class I narcotics not plants in the form of meth , which act was committed by the defendant in the following manner: There had been a criminal act of abuse of class I narcotics for oneself and using narcotics for class I instead of plants, which was allegedly committed by the defendant DIAN RANA PUTRA Alias DIAN Alias PUTRA because he was found carrying , possessing, keeping and controlling narcotics class I types of shabu-shabu.

Starting when the defendant DIAN RANA PUTRA Alias DIAN Alias PUTRA called DPO ASDIR to buy Shabu then the defendant was directed by DPO ASDIR to contact someone to take the methamphetamine, but then the defendant was contacted by telephone by someone the defendant did not know and 
ordered the defendant to meet him nearby. pontong waeapo river crossing. After receiving the person's telephone, the defendant then went to the pontong crossing the Waeapo river to meet the person, after meeting the defendant then bought a package of methamphetamine from that person for Rp. 1,000,000, Rupiah then the defendant returned to the defendant's house. On the way home, the defendant was intercepted by a team from the Buru Island Police Resnarkoba who had received information about the defendant DIAN RANA PUTRA Alias DIAN Alias PUTRA who controlled and consumed shabushabu so that the Buru Island Police Resnarkoba team was the Head of Narcotics Agency (IPTU HANDRY DWI AZHARI), witness BRIGPOL FAHMI WAEL and witness BRIGPOL SAMSUL B. HATUINA who at that time saw something in the defendant's left hand and witness BRIGPOL FAHMI WAEL and witness BRIGPOL SAMSUL B.HATUINA asked the defendant what item was in his left hand and the defendant answered shabushabu then witness BRIGPOL FAHMI WAEL and witness BRIGPOL SAMSUL B. HATUINA asked the defendant to show the methamphetamine which was packaged in a clear plastic clip and wrapped in a tissue, totaling 1 package. Then the defendant together with the evidence for further processing.

\section{the prosecution's demands}

Based on the description referred to above and based on the provisions of the applicable laws and relating to this case, the Public Prosecutor at the Namlea District Prosecutor DEMAND so that it is possible to make a decision against the accused as follows:

a) To declare that the defendant DIAN RANA PUTRA Alias DIAN Alias
PUTRA was legally and convincingly proven guilty of committing the crime of misusing Narcotics Category I for himself in the form of powder and pieces of Methamphetamine crystal (shabu);

b) Imposing the defendant to a sentence of 1 (year) and 2 (month) imprisonment reduced while the Defendant is in temporary detention, with the order of the defendant to remain detained;

c) Evidence

1 (one) red gas lighter with a needle attached. 1 (one) white plastic straw measuring $\pm 14 \mathrm{~cm}$. 1 (one) white plastic straw measuring $\pm 8 \mathrm{~cm} .1$ (one) white plastic straw measuring \pm $10 \mathrm{~cm}$ is currently attached with a blue Aqua bottle cap. 1 (one) pyrex (glass) measuring $\pm 7 \mathrm{~cm} 1$ (one) Huawei brand cellphone owned by the defendant. Seized to be destroyed; Determined that the Defendant paid a court fee of Rp.5,000 (five thousand rupiah).

\section{CONCLUSION}

Based on the research conducted by the author, the writer concludes that in the decision of case number 5 / Pid.Sus / 2020 / $\mathrm{PN} \mathrm{Nla}$, the public prosecutor uses the second indictment, namely Article 127 paragraph (1) letter a of the Republic of Indonesia Law No. 35 of 2009 concerning Narcotics where the elements in the indictment have been deemed proven by the public prosecutor. Where, between the acts and the elements of the article match each other and according to the author, the application of material law in this case is in accordance with the applicable criminal law in Indonesia and in case decision number 5 / Pid.Sus / 2020 / PN Nla, the author agrees with the judge. in applying Article 127 
(UJSS), Vol. 1, No. 2, Agustus 2020: 86-94

paragraph (1) letter a because in this case it can give a warning to the perpetrator not to repeat his actions again.

\section{REFERENCES}

Abdulkadir Muhammad, 2004, Hukum dan Penelitian Hukum, Bandung, Citra Aditya Bakti.

Abdur Rahim, Muhammad H, 2015, Satrio Wirataru, "Hukuman Mati Probem Legalitas", Intrans Institute, Malang,

Andi Hamzah, 2008, Asas Asas Hukum Pidana, Rineka Cipta, Jakarta.

Badan Narkotika Nasional. 2014. Laporan Akhir Survey Nasional Perkembangan Penyalahguna Narkoba Tahun Anggaran 2014, Jakarta.

Dwidja Priyanto, 2006, Sistem Pelaksanaan Pidana Penjara Di Indonesia, Refika Aditama, Bandung.

Marton, Lydia Harlina dan Joewana, Satya. 2008. Peran Orang Tua dalam Mencegah dan Menanggulangi Penyalahgunaan Narkoba, Jakrta: Balai Pustaka.

Syarifin, Pipin, 2008, Hukum Pidana di Indonesia, Bandung: Pustaka Setia

Undang-Undang RI Nomor 35 Tahun 2009 tentang narkotika dan Undang-Undang Nomor 5 tahun 1997 tentang Psikotropika.

Undang-undang Nomor 5 Tahun 1997 Tentang Psikotropika

Undang-undang Nomor 35 Tahun 2009 Tentang Narkotika

Undang-Undang Nomor 8 Tahun 1981 Tentang Kitab Undang-Undang Acara Pidana (KUHAP)

Bin-Tahir, S. Z., Amri, M., Nagauleng, A. M., Diniaty, A., \& Hajar, I. (2019). The Social Media Use For Digital Natives: Parenting Model Of Muslim Cleric Families. International Journal of Scientific \& Technology Research, 8(11), 2871-2874.

Sam, B., Iye, R., Ohoibor, M., Umanailo, M. C. B., Rusdi, M., Rahman, A. B. D., \& Hajar, I. (2019). Female Feminism in the Customary Island of Buru. Int. J. Sci. Technol. Res, 8(8), 1877-1880.

Susiati, S. (2018). Homonim bahasa kepulauan tukang besi dialek kaledupa 
di kabupaten wakatobi [the homonymon of tukang besi island languange in kaledupa dialect at wakatobi regency]. Totobuang, 6 (1), 109, 123.

Iye, R., \& Susiati, S. (2018). NILAI EDUKATIF DALAM NOVEL SEBAIT CINTA DI BAWAH LANGIT KAIRO KARYA MAHMUD JAUHARI ALI (Educative Values in Sebait Cinta di Bawah Langit Kairo by Mahmud Jauhari Ali). Sirok Bastra, 6(2), 185-191.

Susiati, S., Iye, R., \& Suherman, L. O. A. (2019). Hot Potatoes Multimedia Applications in Evaluation of Indonesian Learning In SMP Students in Buru District. ELS Journal on Interdisciplinary Studies in Humanities, 2(4), 556-570.

Susiati, S., \& Iye, R. (2018). Kajian Geografi Bahasa dan Dialek di Sulawesi Tenggara: Analisis Dialektometri. Gramatika: Jurnal Ilmiah Kebahasaan dan Kesastraan, 6(2), 137-151.

Iye, R., Susiati, S., \& Karim, K. (2020). Citra Perempuan dalam Iklan Sabun Shinzui. Sang Pencerah: Jurnal Ilmiah Universitas Muhammadiyah Buton, 6(1), 1-7.

Lafamane, F. (2020). Perkembangan Teori Sastra (suatu Pengantar).

Susiati, S. (2020). GAYA BAHASA SECARA UMUM DAN GAYA BAHASA PEMBUNGKUS PIKIRAN.

Iye, R. (2018). Tuturan emosi mahasiswa kota baubau dalam ranah demonstrasi.

Iye, R., Tenriawali, A. Y., Susiati, A., \& Buton, D. (2020). Makna dan Fungsi Emosi Mahasiswa Kota Baubau dalam Ranah Demonstrasi: The Meaning And Emotional Function Of Students Of Baubau City In The Demonstration Plan. Uniqbu Journal of Social Sciences, 1(1), 25-37. 
Lafamane, F. (2020). Perkembangan Teori Sastra (suatu Pengantar).

Lafamane, F. (2020). Perkembangan Teori Sastra (suatu Pengantar).

Buru, K. M. S. PENGARUH MOTIVASI BELAJAR DI SMA NEGERI 2 BURU.

Yusnan, M., Kamasiah, R. I., Karim, H., \& Bugis, R. (2020). Alih Kode dan Campur Kode pada Novel Badai Matahari Andalusia Karya Hary Elparsia: Transfer Code And Mix Code In Novels Badai Matahari Andalusia Karya Hary El-parsia. Uniqbu Journal of Social Sciences, 1(1), 1-12.

YANTI, K. NILAI-NILAI MORAL DALAM TOKOH UTAMA PADA NOVEL SATIN MERAH.

Susiati, S. (2020). Konsep Pertentangan Dalam Film" Aisyah Biarkan Kami Bersaudara" Karya Herwin Novianto.

Susiati, S. (2020). Gaya Bahasa Secara Umum Dan Gaya Bahasa Pembungkus Pikiran: Stilistika.

Iye, R., Tenriawali, A. Y., Susiati, A., \& Buton, D. (2020). Makna dan Fungsi Emosi Mahasiswa Kota Baubau dalam Ranah Demonstrasi: The Meaning And Emotional Function Of Students Of Baubau City In The Demonstration Plan. Uniqbu Journal of Social Sciences, 1(1), 25-37.

Iye, R. WRITING SKILLS IN SMP USWATUN HASANAH. BURU DISTRICT.

iye, r. (2020, March 10). DEIKSIS MASYARAKAT BONEGUNU KABUPATEN BUTON UTARA. https://doi.org/10.31228/osf.io/seqan. 10.31228/osf.io/seqan. 
Iye, R. (2018). Tuturan dalam Prosesi Lamaran Pernikahan di Tomia Kabupaten Wakatobi. Jurnal Totobuang, 6(2).

Susiati, S. (2020). PENTINGNYA MELESTARIKAN BAHASA DAERAH.

Umanailo, M. C. B. Cia-Cia Vocational Inventoryization In Buru District.

BURU, U. I. MODEL KOOPERATIF LEARNING TIPE STAD DALAM MENINGKATKAN KEMAMPUAN MENGAPRESIASI CERITA FIKSI DI SD NEGERI 1 NAMLEA.

Iye, R. H. NILAI-NILAI MORAL DALAM TOKOH UTAMA PADA NOVEL SATIN MERAH KARYA BRAHMANTO ANINDITO DAN RIE YANTI. TELAGA BAHASA, (7), 2, 195-206.

Lafamane, F. (2020). Perkembangan Teori Sastra (suatu Pengantar).

Iye, R. Jl Prof Dr HAR Basalamah No, and Namlea-Kab Buru.". TUTURAN DALAM PROSESI LAMARAN PERNIKAHAN DI TOMIA KABUPATEN WAKATOBI." Kontemporer. Bandung: PT Remaja.

Harziko, H., Said, I. M., \& Darwis, K. (2018). FOLLOW THE EVENTS IN THE INDONESIAN LANGUAGE EXPRESSIVE SAID TRANSACTION IN THE TRADITIONAL MARKET TOWN OF BAUBAU. JURNAL ILMU BUDAYA, 6(1). 